\section{品野台小学校・香良洲小学校}

Shinanodai Elementary School $\cdot$ Karasu Elementary School
1961年生，1985年豊橋 技術科学大学建設工学 系修士課程修了. 現在, (侏)日建設計 設計室主 管.

若林亮 Makoto Wakabayashi

イキーワード：エコスクール，自然採光，ライトシェルフ，オープンスクール，セットバック

環境に工夫を凝らしている。

\section{1.はじめに}

小学校に求められる基本的な理念が大きく転換しよう としている。

従来の廊下に沿って画一的に教室が並ぶ八モニカ型校 舎の無機質な空間を脱し，子ども達の豊かな生活環境と して校舎を見直し，独創的な思考や，技術か救吼る 時代にあって，画一的な授業から，多様な教育プログラ ムが展開できる環境へと。さらには人工的な照明や泠暖 房に頼らず，積極的に自然の光や風を活かすエコスクー ルへの転換である。

このような校舎に，オープンスクールを思い起こされ るかもしれないが，その学習プログラムを実践される教 師や教育委員会の体制，間仕切りのないオープンな教室 が授業に支障にならないかという䯚念から，全ての新校 舎計画がオープンスクールを前提とはしない，

そのような観点から私たちが設計を担当した二つの公 立小学校を紹介したい. 一つはオープンスクール型の愛 知県瀬戸市の品野台小学校。もう一つは, 従来型の校舎 構成を基本にした三重県香良洲町の香良洲小学校であ る。校舎のつくりは全く異なる小学校ではあるが，それ ぞれ新たな学校建築への取り組みを行い，対応する採光

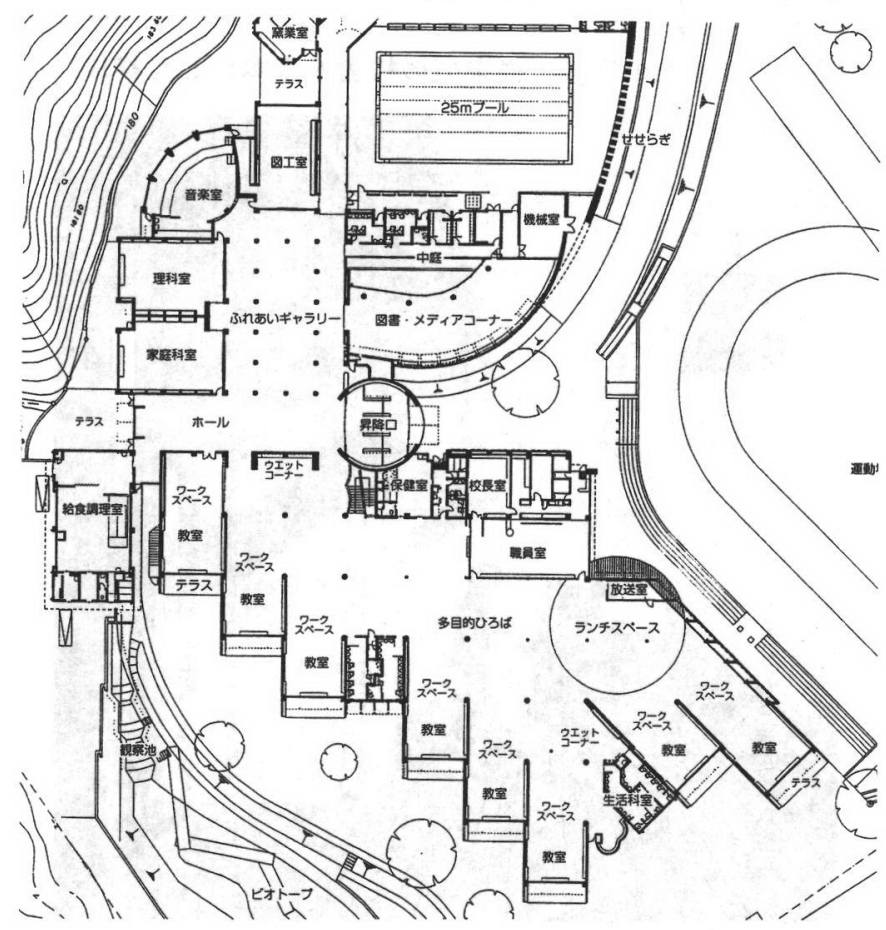

図 1 品野台小学校（オープンスクール型校舎）

\title{
2. 品野台小学校
}

小高い緑の山に囲まれた平屋建て校舎であり，大きな 多目的しろばを囲むように, 應行して教室・ワークスペー スがオープンに配置されている(図1)。

教室は高天井で， $4.5 \mathrm{~m} \sim 2.5 \mathrm{~m}$ と空側に高くなってお ク，深い軒庇と中段に設けられたライトシェルフが特徴 である.一般的な教室の高さ $3 \mathrm{~m}$ の平坦な天井では, 空側 と廊下側でその光環境に著しい差が生じるが，高天井と することで採光面を大きくしライトシェルフを設けて， その反射光を教室の奥まで導くことで，その照度差を少 なくしている(図2, 図3, 図4)。

夏季において，机上の直射光が当たる部分とそうでな い部分のコントラストをつくらないよう，深い軒庇とラ

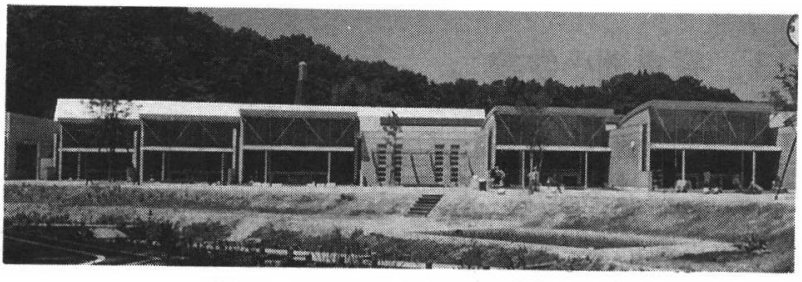

図 2 雁行する教室をみる

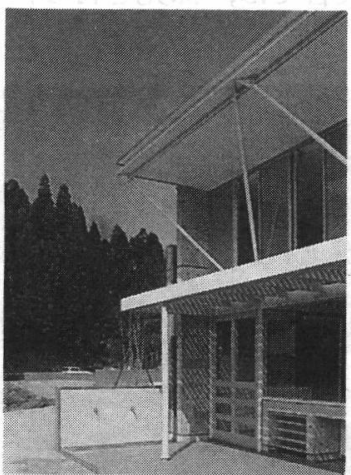

図 3 教室空廻り

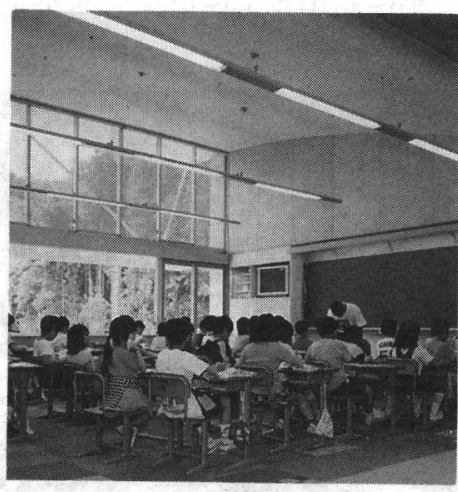

図 4 教室内観
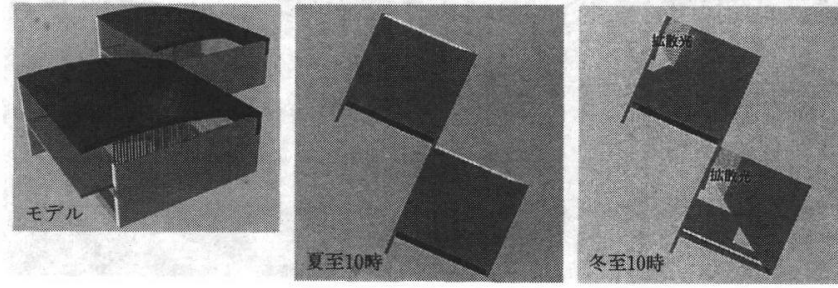

図 5 太陽光と軒の出寸法の検討 
イトシェルフは, その直射光を遮る役割を果たしている。 中間季と冬季の高度の低い太陽光を積極的に採り入れる 上段の空には，その光を和らげるため白いドットを印刷 したフィルムが貼られている（図５）。

一方，教室に連続する多目的ひろばは，多様なプログ ラムを支える教材やパソコンなどの学習メディアが置か れるため, 北に向くハイサイドライトから安定した天空 光を導くノコギリ屋根としている，人工照明は，自然採 光を補うものとして，約 $2.7 \mathrm{~m}$ 間隔の梁下に既製の蛍光 灯をビルトインしている(図6, 図7).

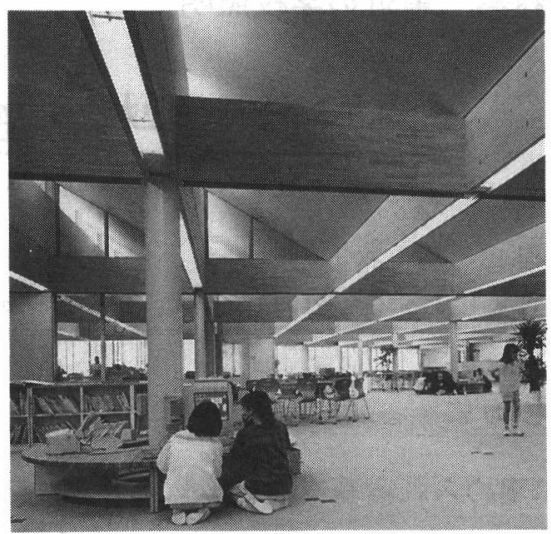

図 6 多目的ひろばノコギリ屋根からの天空光と ビルトインされた蛍光灯照明

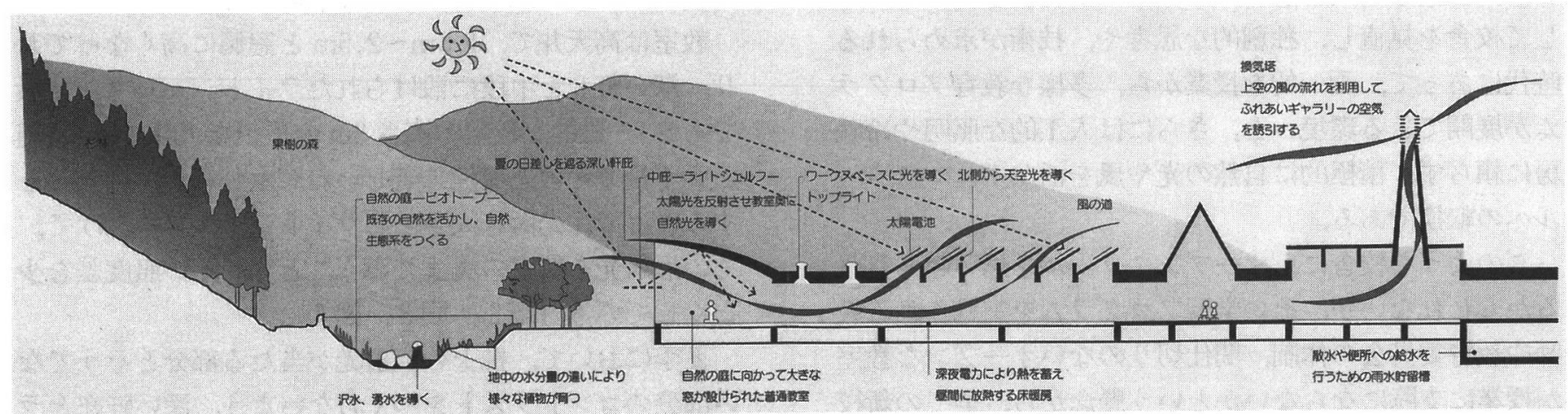

図 7 断面概念図

\section{3. 香良洲小学校}

香良洲小学校は, 従来の八モ二力型教室を基本に構成 されたものであるが，上階にいくほど南側をセットバッ クさせた断面と, 1 学年 2 教室単位で雁行した平面が特 徵である(図8, 図 9 )。

単に教室を上に積んだ従来型校舎では, 採光を得る南

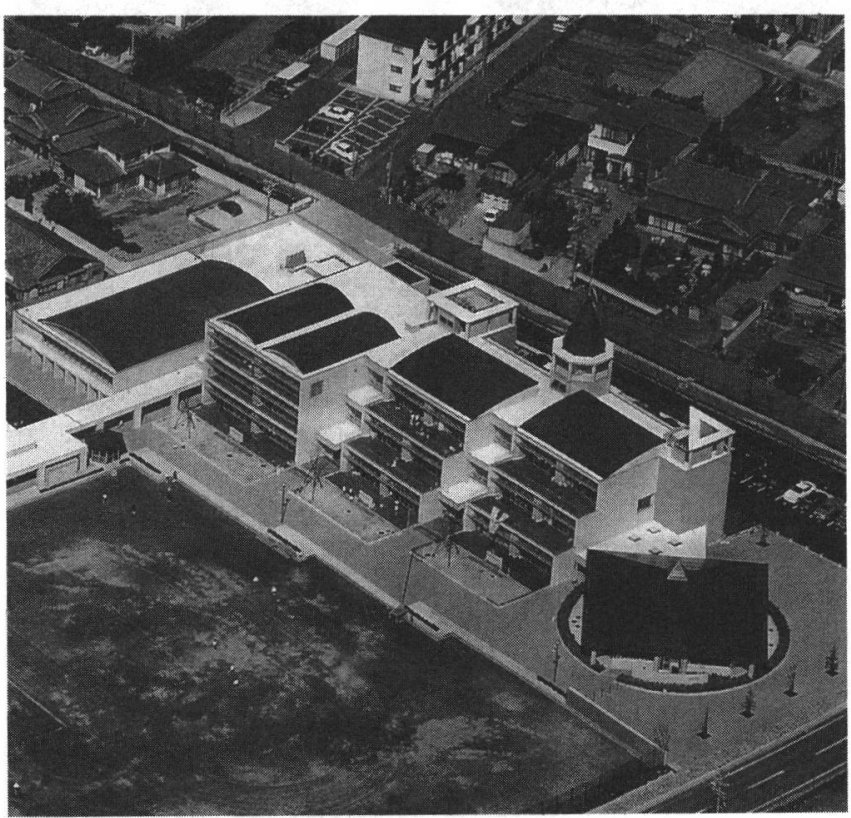

図 9 セットバックした校舎

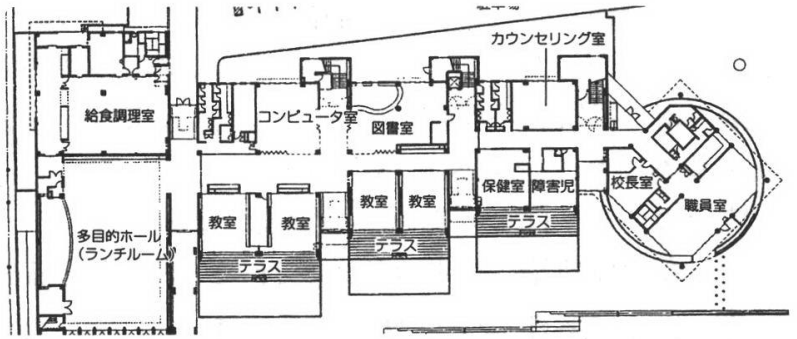

図 8 香良洲小学校（従来型の校舎を基本にした構成）

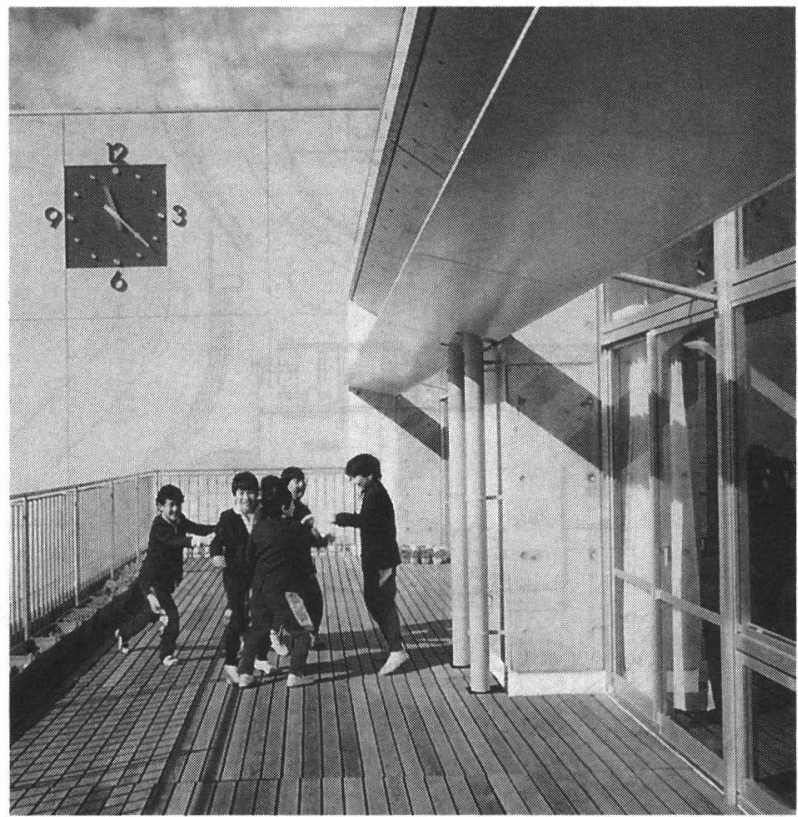

図10 テラス右手が教室のライトシェルフと採光空 
面は, 落下防止のための腰壁や清掃時の安全性から磨り ガラスが使用されるなど，閉鎖的な教室空間になること が常である.しかし，セットバックにより全ての教室が 南側のテラスに面するこの校舎では，床から天井までの 大きな採光空とし，開放的な環境をつくり出している。 光環境としては, 品野台小学校と同様, 軒庇とライトシェ ルフによる構成とし，教室奥まで自然光を導こうとして いる(図10, 図11).

教室が面する廊下は従来型の校舎よりも広くとり，学 習へのきっかけをつくるよう，図書やパソコンが並ぶ北 側採光のメディアコーナーとしている (図12).

2 教室毎の雁行平面の節目には，八イサイドライトの ある 3 層の吹抜が設けられている。これは視線を敢えて 通さず，光のコントラストにより学年単位の空間を意識 させることを意図している(図13，図14）。

香良洲小学校のように, 従来型の八モ二力校舎でも断 面と平面の工夫により，子ども達の生活環境を豊かなも のにすることができる余地は十分にあると考える。

\section{4.おわりに}

当然のことながら，小学校は，朝から日没前まで子ど も達が生活する空間である。常時, 人工照明による均一。 画一的な空間ではなく，陽が照れば教室は明るく，その 陽が雲に隠れれば，その明るさの変化で空の様子が伺え るような環境を創りたいと考えた。人工照明はあくまで それを補うものとして捉えている，照明学会誌への執筆 としては，大変気が引けるところとなった。

また，小学校は地域開放を通じて，そのコミュニティ の拠点として位置づけられている。夜間，地域の人々が 気軽に訪れるには, 気張らない程度のライトアップが必 要であり，このような点もこれからの学校建築には配慮 されるべき点であると考えている。

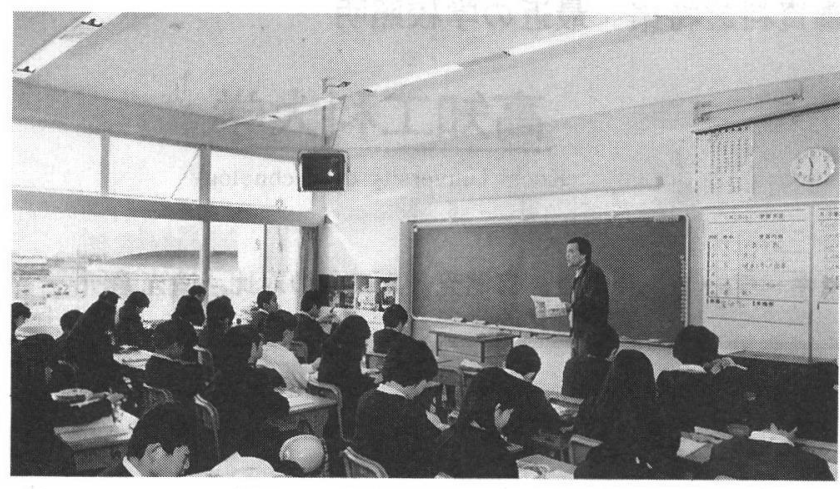

図11自然採光による教室

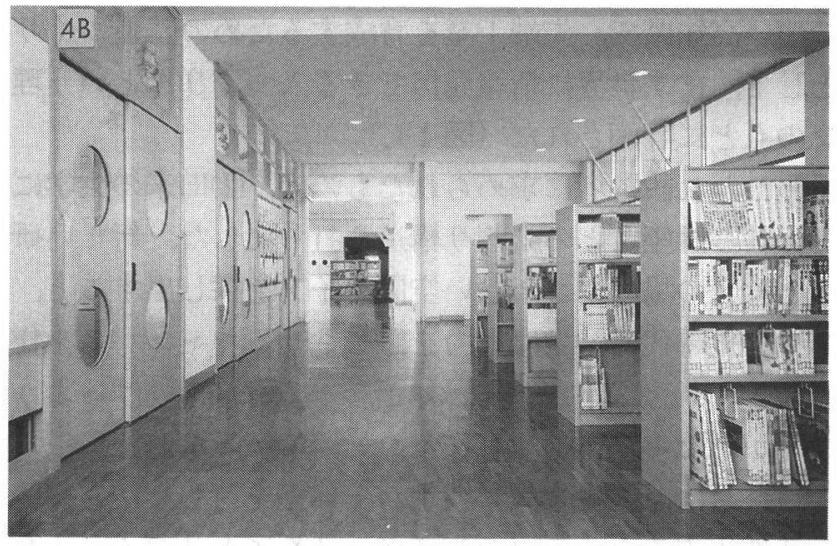

図12＼cjkstart北側採光の学習メディアが並ぶ廊下

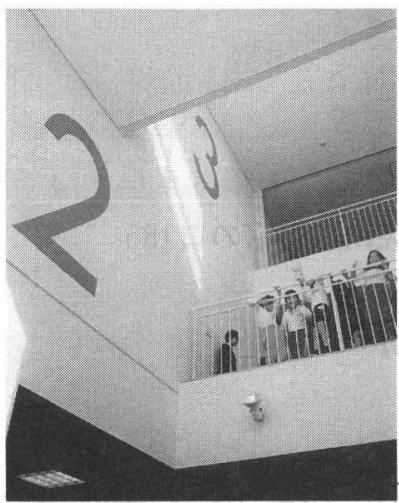

図13雁行の要にある吹抜

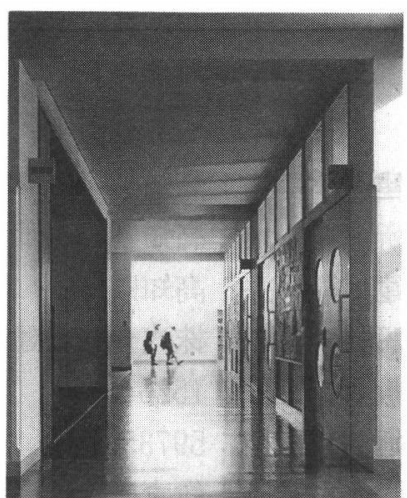

図14 光のコントラスト 